\title{
Effect of Coenzyme Q10 replacement on learning and memory performance in young rats
}

\section{Yavru ratlarda koenzim Q10 replasmanının öğrenme ve bellek performansına etkisi}

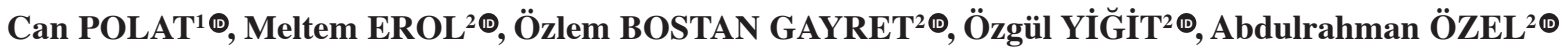

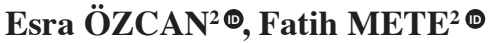

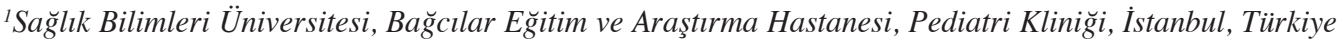 \\ ${ }^{2} S a \breve{g} l ı k$ Bilimleri Üniversitesi Bă̆cılar Eğitim ve Araştırma Hastanesi, Pediatri, İstanbul, Türkiye
}

\begin{abstract}
Objective: Coenzyme Q10 (CoQ10) administration is known to increase CoQ10 concentrations in the mitochondria of brain cells and facilitate the memory and learning processes in rats. This study aims to evaluate the effects of CoQ10 treatment on learning and memory functions in rat pups during early stages of development.

Methods: A total of 21-day-old 24 pups were divided into 3 groups (8 pups in each group). A low dose of CoQ10 was administered via oral gavage once per day to one group, a high dose was administered to another group, and olive oil was administered to the control group. The cognitive and learning functions of rats in these groups were evaluated by the Morris water maze and probe tests.

Results: Coenzyme Q10 administration was continued for 10 days. At the end of the $37^{\text {th }}$ day, the water maze test was used to evaluate learning and memory performance. No difference was observed in the test results among the high-dose, low-dose and control groups during the 5 days of training in the water maze test $(p>0.05)$. Data from the probe trial indicated no statistically significant differences among rats that received high-, or low-dose CoQ10 or olive oil (control) $(\mathrm{p}=0.853)$.

Conclusion: In our study, it was determined that administration of high-, or low-dose CoQ10 during childhood does not have a significant effect on learning and memory functions.
\end{abstract}

Keywords: Coenzyme Q10, learning, memory, rat

$\ddot{0 ̈ z}$

Amaç: Koenzim Q10 (CoQ10) uygulamasının, beyin hücrelerinin mitokondrisinde CoQ10 konsantrasyonlarını arttırdığı ve sıçanlarda bellek ve öğrenme süreçlerini kolaylaştırdığı bilinmektedir. Bu çalışma, erken çocukluk dönemindeki yavru ratlarda CoQ10 tedavisinin öğrenme ve bellek üzerine etkilerini değerlendirmeyi amaçlamaktadır.

Yöntem: Toplam 24 adet 21 günlük yavru 3 gruba ayrılmıştır (her grupta 8 yavru). Bir gruba günde bir kez ağızdan gavaj yoluyla düşük dozda CoQ10 uygulanmışken diğer gruba yüksek dozda uygulanmıştır, kontrol grubuna ise zeytinyağı uygulanmıştır. Ratların öğrenme ve hafıza işlevleri, Morris su labirenti ve prob test ile değerlendirilmiştir.

Bulgular: Koenzim Q10 uygulamasına 10 gün süreyle devam edilmiştir. Otuz yedinci günün sonunda, öğrenme ve bellek performansını değerlendirmek için su labirenti testi kullanılmıştır. Su labirenti testinde 5 günlük eğitim boyunca yüksek doz, düşük doz ve kontrol grupları arasındaki test sonuçlarında herhangi bir fark gözlenmemiştir $(p>0,05)$. Prob deneyinden elde edilen veriler, yüksek doz CoQ10, düşük doz CoQ 10 veya zeytinyağı (kontrol) alan ratlar arasında istatistiksel olarak anlamlı farklar olmadığını göstermiştir $(\mathrm{p}=0,853)$

Sonuç: Çalışmamızda, çocukluk döneminde yüksek doz ve düşük doz CoQ10 uygulamasının öğrenme ve bellek fonksiyonları üzerinde anlamlı bir etkisi olmadığı saptanmıştır.

Anahtar kelimeler: Koenzim Q10, öğrenme, hafıza, rat

Alındığı tarih: 11.08.2018

Kabul tarihi: 09.09.2018

Yazışma adresi: Doç. Dr. Meltem Erol, Sağlık Bilimleri Üniversitesi Bağcılar Eğitim ve Araştırma Hastanesi Çocuk Kliniği, İstanbul - Türkiye e-mail: drmeltemerol@yahoo.com

Yazarların ORCID bilgileri:

C.P. 0000-0001-7700-6652

M.E. 0000-0002-7672-1854

Ö.B.G. 0000-0003-4121-8009

Ö.Y. 0000-0002-9738-2388

A.Ö. 0000-0001-8947-420X

E.Ö. 0000-0002-9738-2388

F.M. 0000-0002-1572-1033 


\section{INTRODUCTION}

Coenzyme Q10 (CoQ10) is a lipophilic, endogenic antioxidant and the main component of quinol involving in the mitochondrial electron transport chain and is similar to a fat-soluble vitamin. Coenzyme Q10 is a redox molecule that is biochemically available in both its reduced (ubiquinol-10) and oxidized forms (ubiquinone-10) in biological tissues and exerts many functions. Coenzyme Q10 functions in mitochondria as an electron carrier in the respiratory chain ${ }^{(1)}$. Coenzyme Q10 prevents lipid peroxidation and biomolecular damage by interacting with oxygenderived radicals and singlet oxygen atoms, and this molecule functions as an intermediate product with free radicals and is often exposed to electron reduction reactions. Unstable free radicals become stable with an electron coming from ubiquinone. This characteristic makes coenzyme Q10 an important antioxidant ${ }^{(2)}$. Ubiquinol-10 is the first antioxidant to react if the plasma is exposed to oxidants despite its low concentrations when compared to other antioxidants in the plasma, such as alpha-tocopherol. Coenzyme Q10 can also augment the regeneration of other antioxidants ${ }^{(1,2)}$. Furthermore, it has been reported that CoQ10 has positive effects on membrane stability, cell signaling, gene expression, control of cell growth and apoptosis, prevention and treatment of cardiovascular and neurodegenerative diseases and some types of cancer; additionally, this compound is known to delay aging ${ }^{(3)}$. Coenzyme Q10 supplementation has been reported to be beneficial for the treatment of cardiovascular diseases, cancer, diabetes, hypertension and neurodegenerative diseases ${ }^{(4)}$. Coenzyme Q 10 administration is also known to increase the CoQ10 concentration in the mitochondria of brain cells in rats and to facilitate memory and learning processes ${ }^{(5)}$. Cognitive deficits in a surgically induced menopausal rodent model were ameliorated upon treatment with CoQ10 ${ }^{(6)}$. There are few studies in the literature on neurocognitive functions and learning during early childhood. The purpose of our study was to evaluate the effect of low-, and high-dose CoQ10 supplementation on learning and memory abilities in rats during childhood.

\section{MATERIALS and METHODS}

A gelatin capsule containing $30 \mathrm{mg}$ coenzyme Q10 (Solgar, New Jersey, USA) was provided. A low $(0.72 \mathrm{mg} / \mathrm{g})$ or high dose $(2.6 \mathrm{mg} / \mathrm{g})$ of CoQ10 was administered via oral gavage once a day for 10 days. Coenzyme Q10 was dissolved in water $(1 \mathrm{ml} / \mathrm{kg}$ bwt/d).

\section{Experimental animals and groups}

Wistar-Hannover rats were provided by the XXX, Experimental Research and Skill Development Center Laboratory. The study was approved by the Local Ethics Committee (project no: 2015-40) in accordance with the instructions regarding the care and usage of laboratory animals stated in the Declaration of Helsinki.

During the study, rats were kept in groups of four in polycarbonate cages at a temperature of $20 \pm 2^{\circ} \mathrm{C}$ and $50 \pm 5 \%$ humidity under $12 / 12$ hour light/dark cycles. Rats were provided with unlimited water and standard laboratory rat chows. When the pups were weaned at 21 days old, they were divided by gender.

\section{Experimental animals and groups}

Three groups of pups were formed with each group consisting of 8 pups (4 males and 4 females). The pups were randomly chosen from different litters. The groups were treated as follows:

1. High-dose $(2.6 \mathrm{mg} / \mathrm{kg} /$ day $)$ CoQ10

2. Low-dose $(0.72 \mathrm{mg} / \mathrm{kg} /$ day $)$ CoQ10

3. Water (control group)

Coenzyme 10 dissolved in water $(1 \mathrm{ml} / \mathrm{kg}$ body weight/day) was administered by oral gavage once a day for 10 days, and the same volume of water was administered to the control group via oral gavage. The dose of CoQ10 was determined based on the literature ${ }^{(5)}$. At the postnatal day (PND) 37, the learning and memory functions of the rats were evaluated by the Morris water maze (MWM) test.

\section{Morris Water Maze Test}

Morris Water Maze is an important method for 
evaluating cognitive and spatial learning ${ }^{(7)}$. Spatial acquisition and spatial learning are the basic principles underlying the MWM. Because of its many characteristic features, the MWM is widely used. For this test, water at a temperature of $26 \pm 2^{\circ} \mathrm{C}$ was added into a pool $120-200 \mathrm{~cm}$ in width and $50 \mathrm{~cm}$ in height, and the water was added into the chamber up to 23-30 cm in height The escape platform was placed in the center of one of the quadrants in the pool. The platform was a minimum of $10 \mathrm{~cm}$ in diameter and $0.5-1 \mathrm{~cm}$ elevated from the water level. Various pictures were hung around the room in which the pool was located, and the room was completely decorated. The water clarity was reduced by adding white powder to the water.

\section{Morris water maze learning performance}

The position of the tank and platform location was kept constant during the test. Two swimming trainings were performed per day, and acquisition training was conducted for 4 days. The fifth day was determined as the test application day. The rats were left on the platform for 30 seconds to recognize the escape platform in the tank before being released into the water on the first day. Then, each rat was released to the farthest point away from the platform and observed while the rat was trying to find the platform within 90 seconds. The rats, which could not find the platform, were guided to the platform with the help from behind and left on the platform for 10 seconds and then taken back to the cage. Each rat was released into the water from a different quarter with 30 minutes between the experiments. During the experiments, the duration of the rats on the escape platform was recorded by a digital chronometer. For evaluation, the longevities of rats stay on the escape platform were compared.

\section{Probe trial test:}

It was conducted 24 hours after the five-day test. In this test, the platform was taken out from the tank, and the subjects were floated on it. Naturally rats did more searching in the quarter of the tank where the platform had been previously. This period refers to the consolidation of memory. The longevities of swimming of the rats in the quarter part of the area within the range of the old platform were recorded. The percentage of the duration spent in the target quadrant by groups was calculated and compared.

\section{Statistical Evaluation}

In this study, statistical analyses were performed using the NCSS (Number Cruncher Statistical System) 2007 Statistical Software (Utah, USA) package. In the evaluation of the data, descriptive statistical methods (mean, standard deviation) as well as the repeated measures analysis of variance in multiple groups, the Newman-Keuls multiple comparison test in subgroup comparisons, and one-way analysis of variance in intergroup comparisons were used. The results were evaluated at the level of statistical significance of $\mathrm{p}<0.05$.

\section{RESULTS}

\section{Body weight}

The mean body weights of the rats at the beginning of the study were $45.75 \pm 1.28 \mathrm{~g}$ for the control, $45.50 \pm 1.30 \mathrm{~g}$ for the high-, and $45.88 \pm 1.12 \mathrm{~g}$ for the low-dose groups.. No statistically significant differences were found among the weights of the rats at the beginning of the study ( $\mathrm{p}=0.829)$. The final mean weights of the control $(118.13 \pm 1.8 \mathrm{~g})$, high $(118.5 \pm 1.51 \mathrm{~g})$, and the low-dose $(118.63 \pm 1.68 \mathrm{~g})$ groups were as indicated without any statistically significant differences among the groups $(\mathrm{p}=0.735)$. The differences between the first and last measurements of the mean body weights were $72.38 \pm 2.44 \mathrm{~g}$ in the control; $72.50 \pm 2.61 \mathrm{~g}$ in the high-, and $72.75 \pm 2.34 \mathrm{~g}$ in the low-dose groups, without any significant differences among groups $(\mathrm{p}=0.955)$.

\section{Morris water maze learning performance}

No statistically significant difference was observed between the mean scores measured on the $1^{\text {st }}, 2^{\text {nd }}$, $3^{\text {rd }}, 4^{\text {th }}$ and $5^{\text {th }}$ test days in all three groups $(\mathrm{p}>0.05)$ (Table 1). There were statistically significant differences between the mean durations of stay on the platform on the $1^{\text {st }}, 2^{\text {nd }}, 3^{\text {rd }}, 4^{\text {th }}$ and $5^{\text {th }}$ days for the high-, low-dose, and control groups (for each 
$\mathrm{p}=0.0001$ ). For all groups, the mean durations of stay on the platform on the fifth day were significantly shorter compared to the other days. The p-values of the mean durations of staying on the platform on the test days for the groups are presented in Table 2.

\section{Probe trial test:}

Data from the probe trial, which measures how well the animals had learned and consolidated the platform location during the 5 days of training, showed that there was no significant difference between the groups $(\mathrm{p}=0.853)$ (Table 3$)$.

Table 1. Durations of finding the platform by days for each group.

\begin{tabular}{lcccc}
\hline & $\begin{array}{c}\text { Control } \\
\text { Group }\end{array}$ & $\begin{array}{c}\text { Low-Dose } \\
\text { Group }\end{array}$ & $\begin{array}{c}\text { High-Dose } \\
\text { Group }\end{array}$ & p \\
\hline $1^{\text {st }}$ test day & $35.38 \pm 0.79$ & $34.81 \pm 1.46$ & $34.86 \pm 0.92$ & 0.534 \\
$2^{\text {nd }}$ test day & $23.44 \pm 1.10$ & $22.44 \pm 1.17$ & $22.61 \pm 1.10$ & 0.188 \\
$3^{\text {rd }}$ test day & $19.65 \pm 2.11$ & $19.21 \pm 1.72$ & $19.21 \pm 1.19$ & 0.842 \\
$4^{\text {th }}$ test day & $17.00 \pm 1.34$ & $17.19 \pm 1.13$ & $16.71 \pm 1.38$ & 0.762 \\
$5^{\text {th }}$ test day & $14.74 \pm 0.51$ & $15.20 \pm 0.88$ & $15.05 \pm 0.72$ & 0.438 \\
$\mathrm{p}$ & 0.0001 & 0.0001 & 0.0001 & \\
& & & & \\
\hline
\end{tabular}

Table 2. Multiple comparison test results of the durations of finding the platform by days for each group.

\begin{tabular}{lccc}
\hline $\begin{array}{l}\text { Newman-Keusl Multiple } \\
\text { Comparison Test }\end{array}$ & $\begin{array}{c}\text { Control } \\
\text { Group }\end{array}$ & $\begin{array}{c}\text { Low-Dose } \\
\text { Group }\end{array}$ & $\begin{array}{c}\text { High-Dose } \\
\text { Group }\end{array}$ \\
\hline $1^{\text {st }}$ day / $2^{\text {nd }}$ day & 0.0001 & 0.0001 & 0.0001 \\
$1^{\text {st }}$ day / $3^{\text {rd }}$ day & 0.0001 & 0.0001 & 0.0001 \\
$1^{\text {st }}$ day / $4^{\text {th }}$ day & 0.0001 & 0.0001 & 0.0001 \\
$1^{\text {st }}$ day / $5^{\text {th }}$ day & 0.0001 & 0.0001 & 0.0001 \\
$2^{\text {nd }}$ day / $3^{\text {rd }}$ day & 0.001 & 0.001 & 0.002 \\
$2^{\text {nd }}$ day / 4 $4^{\text {th }}$ day & 0.0001 & 0.0001 & 0.0001 \\
$2^{\text {nd }}$ day / $5^{\text {th }}$ day & 0.0001 & 0.0001 & 0.0001 \\
$3^{\text {rd }}$ day / $4^{\text {th }}$ day & 0.011 & 0.002 & 0.0001 \\
$3^{\text {rd }}$ day / $5^{\text {th }}$ day & 0.0001 & 0.0001 & 0.0001 \\
$4^{\text {th }}$ day / $5^{\text {th }}$ day & 0.003 & 0.0001 & 0.001 \\
\hline
\end{tabular}

Table 3. Comparison of the Percentage of the Duration Spent in the Target Quadrant by groups.

\begin{tabular}{|c|c|c|}
\hline $\begin{array}{l}\text { Control } \\
\text { Group }\end{array}$ & $\begin{array}{l}\text { Low-Dose } \\
\text { Group }\end{array}$ & $\begin{array}{c}\text { High-Dose } \\
\text { Group }\end{array}$ \\
\hline
\end{tabular}

Percentage of the $31.00 \pm 13.53 \quad 34.15 \pm 10.77 \quad 31.85 \pm 9.95 \quad 0.853$ Duration Spent

in the Target

Quadrant

\section{DISCUSSION}

This study was conducted to elucidate the effect of CoQ10 on learning function at a young age. Coenzyme Q10 was used in the treatment of oxidative damage and impairments resulting from inadequate cellular energy metabolism. Coenzyme Q10 is a supplemental factor for impaired energy metabolism and is therefore considered suitable for use in the treatment of cardiac, neurologic, oncologic and immunologic diseases ${ }^{(5)}$. Coenzyme Q10 exerts positive effects on the memory and learning functions; however, studies reporting these data were conducted to evaluate learning functions in adults and postmenopausal women ${ }^{(6,8)}$. As a result of the recovery of the mitochondrial electron transport system due to CoQ10 replacement cognitive functions improved in experimental models of Alzheimer's disease and Parkinson's disease ${ }^{(9,10)}$.

Reduced estrogen levels have been shown to decrease mitochondrial functions in postmenopausal women due to oxidative stress, and as a result, cognitive functioning declines ${ }^{(6)}$. The administration of CoQ10 at a prophylactic dose of $10 \mathrm{mg} / \mathrm{kg}$ was observed to protect neurons against traumatic brain injury, cerebral ischemia, tissue ischemia-reperfusion injury and spinal cord trauma ${ }^{(11-13)}$. In another study, it was observed that CoQ10 administration for 3 weeks did not prevent neural damage after focal or global cerebral ischemia ${ }^{(14)}$. CoQ10 administration $(0.7 \mathrm{mg} / \mathrm{kg} /$ day) to rats for 6 months was observed to delay the detrimental effects of aging on the brain ${ }^{(15)}$. In vitro studies have shown that CoQ10 usage at a concentration of $6.25 \mu \mathrm{M}$ prevents oxidative stress and neurotoxicity ${ }^{(16)}$. The administration of $10 \mathrm{mg} / \mathrm{kg}$ CoQ10 to rats with their diet for one month showed a significant reduction in protein carbonyl formation in the brain in a patient with Alzheimer's disease ${ }^{(17)}$. The components of the electron transport chain in the inner mitochondrial membrane regulate redox reactions; therefore, adenosine triphosphate (ATP) is synthesized from adenosine diphosphate (ADP) and free phosphates. The levels of enzymes of the mitochondrial electron transport chain in the brain namely cytochrome c reductase, succinate dehydrogenase 
and cytochrome c oxidase decreased in mice ovarectomized to create a menopausal model ${ }^{(6)}$. In this study, it was observed that CoQ10 replacement repaired enzyme activity. The impairment in the electron transport chain resulting from this hormone deficiency in rats induces formation of free radicals and increase in oxidative stress, both of which distort the integrity of the mitochondria ${ }^{(6,18)}$. This causes decline in learning consciousness functions. The decline in postmenopausal learning functions is considered to result from this mechanism.

Coenzyme Q10 reduces oxidative stress by ensuring electron transport from Complex I to Complex III, and it also reduces the damage in the electron transport chain. Therefore, this molecular pairs the damage to learning functions ${ }^{(18)}$.

In our study, CoQ10 replacement therapy was observed to have no significant effect on learning and memory functions in healthy young rats. In a study conducted by Shetty et al. ${ }^{(5)}$, administration of a low dose of CoQ10 (96 mg/kg/day) as a replacement treatment to an aged mice for 16 weeks did not have a significant effect on learning functions, while high dose CoQ10 (457 mg/kg/day) replacement treatment for the same period was reported to have a positive effect on age-related learning functions. When tissue analysis was performed in the same study, the highdose replacement treatment was observed to decrease protein oxidation in the mitochondria. That study also reported that high-dose CoQ10 replacement had a negative effect on hearing function in healthy young mice and that long-term replacement treatment had negative effects on brain functions and learning; therefore, initiating the replacement treatment in older animals was more suitable ${ }^{(5)}$.

The age-related decline in hippocampal and cortical functions in mice and rats was evaluated in previous studies using the MWM test ${ }^{(7,19)}$. In a study conducted by Sumien et al. ${ }^{(20)}$, long-term administration of low-dose CoQ10 was observed to cause significant changes in the conscious functions in aged mice. It was also observed that high-dose CoQ10 treatment in aged mice caused an exaggerated response in some cognitive functions and damaged hearing functions ${ }^{(20)}$.
It was reported that short-term administration of high-dose CoQ10 replacement in middle-aged (18-month-old) mice did not have much of an effect on the increase in sportive activities, anti-aging and psychomotor functions ${ }^{(21)}$.

Additionally, administration of high-dose CoQ10 replacement therapy in this group of young mice (4-month-old) did not have a significant effect on psychomotor functions ${ }^{(22)}$.

Furthermore, in studies of rats and mice, longterm CoQ10 treatment in adulthood was observed to have no effect on their lifespan ${ }^{(23)}$. Our results did not show any significant effect of CoQ10 supplementation on body weight. Many reports in the literature have described the therapeutic benefit of CoQ10 supplementation in glycemic control and insulin resistance ${ }^{(24)}$. In a previous study, it was reported that CoQ10 supplementation did not affect weight gain in rats ${ }^{(25)}$. Our results are in accordance with this study.

According to the results of studies previously conducted, high-dose CoQ10 replacement is beneficial in repairing the neurocognitive functions impaired due to oxidative stress and disorders of consciousness resulting from age-derived mitochondrial damage. However, our study was conducted with a population of young rats. Both high-, and low-dose treatments were insignificant regarding the evaluation of conscious function using the water maze test.

The reason for this is that the rats were young and completely healthy without being exposed to oxidative stress. This shows that CoQ10 administration in young and healthy individuals has no effect on learning function. Furthermore, the detrimental effects of long-term high-dose CoQ10 administration in young mice have been mentioned in the literature. No side effects were observed in our study, presumably due to relatively shorter treatment period.

This is the first study that investigated the effects of CoQ10 administration on the performance of learning and memory in a young population which was the strength and novelty of our study. However, the primary weakness of our study was its small sample size. 


\section{CONCLUSION}

In our study, high-, and low-dose CoQ10 administration during childhood does not have a significant effect on learning and memory functions. Our study results suggested that CoQ10 administration does not exert a beneficial effect in young and healthy rats with regard to learning and memory performance.

This study was presented as an oral presentation in 60. Turkish National Pediatrics Congress, 2016.

\section{REFERENCES}

1. Ernster L, Dallner G. Biochemical, physiological and medical aspects of ubiquinone function. Biochim Biophys Acta. 1995;1271:195-204. https://doi.org/10.1016/0925-4439(95)00028-3

2. Overvad K, Diamant B, Holm L, Holmer G, Mortensen SA, Stender S. Coenzyme Q10 in health and disease. Eur J Clin Nutr. 1999;53:764-70. Review. https://doi.org/10.1038/sj.ejcn.1600880

3. Ames BN. Micronutrients prevent cancer and delay aging. Toxicol Lett. 1998;28:5-18. Review. https://doi.org/10.1016/S0378-4274(98)00269-0

4. Dhanasekaran M, Ren J. The emerging role of coenzyme Q-10 in aging, neuro degeneration, cardiovascular disease, cancer and diabetes mellitus. Curr Neurovasc Res. 2005;2:447-59. Review. https://doi.org/10.2174/156720205774962656

5. Shetty RA, Forster MJ, Sumien N. Coenzyme Q (10) supplementation reverses age-related impairments in spatial learning and lowers protein oxidation. Age. 2013;35:1821-34. https://doi.org/10.1007/s11357-012-9484-9

6. Sandhir R, Sethi N, Aggarwal A, Khera A. Coenzyme Q10 treatment ameliorates cognitive deficits by modulating mitochondrial functions in surgically induced menopause. Neurochem Int. 2014;74:16-23. https://doi.org/10.1016/j.neuint.2014.04.011

7. Morris R. Developments of a water-maze procedure for studying spatial learning in the rat. J Neurosci Methods. 1984;11:47-60. https://doi.org/10.1016/0165-0270(84)90007-4

8. Shetty RA, Ikonne US, Forster MJ, Sumien N. Coenzyme Q10 and $\alpha$-tocopherol reversed age-associated functional impairments in mice. Exp Gerontol. 2014;58:208-18. https://doi.org/10.1016/j.exger.2014.08.007

9. Dumont M, Kipiani K, Yu F, Wille E, Katz M, Calingasan NY, et al. Coenzyme Q10 decreases amyloid pathology and improves behavior in a transgenic mouse model of Alzheimer's disease. J Alzheimers Dis. 2011;27:211-23. https://doi.org/10.3233/JAD-2011-110209

10. Mischley LK, Allen J, Bradley R. Coenzyme Q10 deficiency in patients with Parkinson's disease. J Neurol Sci. 2012;318:72-5. https://doi.org/10.1016/j.jns.2012.03.023

11. Kalayci M, Unal MM, Gul S, Acikgoz S, Kandemir N, Hanci $\mathrm{V}$, et al: Effect of Coenzyme Q10 on ischemia and neuronal damage in an experimental traumatic brain-injury model in rats. BMC Neurosci. 2011;12:75.

https://doi.org/10.1186/1471-2202-12-75

12. Ostrowski RP. Effect of coenzyme Q10 (CoQ10) on superoxide dismutase activity in ET-1 and ET-3 experimental models of cerebral ischemia in the rat. Folia Neuropathol. 1999;37:247-51.

13. Kerimoglu A, Pasaoglu O, Kanbak G, Hanci V, Ozdemir F, Atasoy MA. Efficiency of Coenzyme Q (10) at experimental spinal cord injury. Ulus Travma Acil Cerrahi Derg. 2007;13:85-93.

14. Li H, Klein G, Sun P, Buchan AM. CoQ10 fails to protect brain against focal and global ischemia in rats. Brain Res. 2000;877:7-11. https://doi.org/10.1016/S0006-8993(00)02609-3

15. Ochoa JJ, Pamplona R, Ramirez-Tortosa MC, GranadosPrincipal S, Perez-Lopez P, Naudí A, et al. Age-related changes in brain mitochondrial DNA deletion and oxidative stress are differentially modulated by dietary fat type and coenzyme Q 10. Free Radic Biol Med. 2011;50:1053-64. https://doi.org/10.1016/j.freeradbiomed.2011.02.004

16. Quinn J, Suh J, Moore MM, Kaye J, Frei B. Antioxidants in Alzheimer's disease- vitamin C delivery to a demanding brain. J Alzheimers Dis. 2003;5:309-13. https://doi.org/10.3233/JAD-2003-5406

17. Wadsworth TL, Bishop JA, Pappu AS, Woltjer RL, Quinn JF. Evaluation of coenzyme $Q$ as an antioxidant strategy for Alzheimer's disease. J Alzheimers Dis. 2008;14:225-34. https://doi.org/10.3233/JAD-2008-14210

18. Su Y, Sun H, Fang J, Hu G, Xiao M. Brain mitochondrial dysfunction in ovariectomized mice injected with D-galactose. Neurochem Res. 2010;35:399-404. https://doi.org/10.1007/s11064-009-0068-8

19. Brandeis R, Brandys Y, Yehuda S. The use of the Morris water maze in the study of memory and learning. Int $\mathbf{J}$ Neurosci. 1989;48:29-69. https://doi.org/10.3109/00207458909002151

20. Sumien N, Sims MN, Taylor HJ, Forster MJ. Profiling psychomotor and cognitive aging in four-way cross mice. Age. 2006;28:265-82. https://doi.org/10.1007/s11357-006-9015-7

21. Kolb B, Sutherland RJ, Whishaw IQ. A comparison of the contributions of the frontal and parietal association cortex to spatial localization in rats. Behav Neurosci. 1983;97:13-27. https://doi.org/10.1037/0735-7044.97.1.13

22. Gage FH, Dunnett SB, Bjorklund A. Spatial learning and motor deficits in aged rats. Neurobiol Aging. 1984;5:43-8. https://doi.org/10.1016/0197-4580(84)90084-8

23. Sohal RS, Kamzalov S, Sumien N, Ferguson M, Rebrin I, Heinrich KR, et al. Effect of coenzyme Q10 intake on endogenous coenzyme $\mathrm{Q}$ content, mitochondrial electron transport chain, antioxidative defenses, and life span of mice. Free Radic Biol Med. 2006;40:480-7. https://doi.org/10.1016/j.freeradbiomed.2005.08.037

24. Singh RB, Niaz MA, Rastogi SS, Shukla PK, Thaku AS. Effect of hydrosoluble CoQ10 on blood pressure and insulin resistance in hypertensive patients with coronary artery disease. J Hum Hypertens. 1999;13:203-8. https://doi.org/10.1038/sj.jhh.1000778

25. Lazourgui MA, El-Aoufi S, Labsi M, Maouche B. Coenzyme Q10 supplementation prevents iron overload while improving glycaemic control and antioxidant protection in insulinresistant psammomysobesus. Biol Trace Elem Res. 2016;173:108-15. https://doi.org/10.1007/s12011-016-0617-3 